Article

\title{
Endophyte Bacillus velezensis Isolated from Citrus spp. Controls Streptomycin-Resistant Xanthomonas citri subsp. citri That Causes Citrus Bacterial Canker
}

\author{
Muhammad Fazle Rabbee ${ }^{\dagger}$, Md. Sarafat Ali ${ }^{\dagger}$ and Kwang-Hyun Baek * \\ Department of Biotechnology, Yeungnam University, Gyeongsan, Gyeongbuk 38541, Korea \\ * Correspondence: khbaek@ynu.ac.kr; Tel.: +82-53-810-3029 \\ + Both authors contributed equally to this work.
}

Received: 10 July 2019; Accepted: 17 August 2019; Published: 20 August 2019

\begin{abstract}
Citrus bacterial canker $(\mathrm{CBC})$, caused by the plant pathogenic bacterium Xanthomonas citri subsp. citri $(\mathrm{Xcc})$, is a devastating disease in many commercial citrus cultivars. Every year, CBC causes a substantial reduction in fruit quality and quantity that corresponds to significant economic losses worldwide. Endophytic microorganisms produce numerous bioactive secondary metabolites that can control plant pathogens. We investigated the antagonistic activities of 66 endophytic bacteria isolated from nine citrus cultivars to control streptomycin-resistant Xcc. The suspension of Endophytic Bacteria-39 (EB-39), identified as Bacillus velezensis, exhibited the highest antibacterial activity against three wild-type and six streptomycin-resistant Xcc strains, with the inhibition zones between $39.47 \pm 1.6$ and $45.31 \pm 1.6 \mathrm{~mm}$. The ethyl acetate extract of EB-39 also controlled both wild-type and streptomycin-resistant Xcc strains, with the inhibition zones between $29.28 \pm 0.6$ and $33.88 \pm 1.3 \mathrm{~mm}$. Scanning electron microscopy indicated the ethyl acetate extract of EB-39-induced membrane damage and lysis. The experiments using the detached leaves of a susceptible Citrus species showed that EB-39 significantly reduced the incidence of canker on the infected leaves by $38 \%$. These results strongly suggest that our newly isolated EB-39 is a novel biocontrol agent against CBC caused by wild-type and streptomycin-resistant Xcc strains.
\end{abstract}

Keywords: Bacillus velezensis; citrus bacterial canker; endophyte; streptomycin-resistance

\section{Introduction}

Citrus species are fruit crops that can be found worldwide, and they have high value in both fresh and processed fruit industries [1]. Because of the increasing demand for citrus fruits and juices, the global production of citrus fruit for 2018-2019 was forecast to expand from 4.2 million metric tons in the previous year to 51.8 million metric tons as favorable weather leads to larger crops in Brazil and the United States [2]. Citrus fruits are very popular worldwide for their flavor, and they are the source of secondary metabolites, such as flavonoids with anti-inflammatory and antimicrobial activities. Flavonoids, such as hesperetin, naringenin, eriodictyol, and isosakuranetin, have been investigated for their possible roles in the prevention of life-threatening cardiovascular diseases and cancer [3].

Citrus bacterial canker (CBC) is the most severe and contagious disease of Citrus spp. and cultivars [4-6]. The severity of this disease was first reported around 1912 in Florida, and it spread throughout the U.S. as a result of imported seedlings from Japan [4]. To date, three distinct types of $\mathrm{CBC}$ have been reported-types $\mathrm{A}, \mathrm{B}$, and $\mathrm{C}$ - and they are caused by different pathovars and variants of the strain Xanthomonas [4,7,8]. CBC type A (Asiatic type of canker) caused by X. citri subsp. citri (Xcc), previously named $X$. axonopodis pv. citri, is the most destructive and widespread form of the disease in C. paradisi (grapefruit) and C. aurantifolia (Mexican lime) [8]. CBC types B and C are caused by X. fuscans 
subsp. aurantifolii strain B and X. fuscans subsp. aurantifolii strain C, respectively [6]. CBC type B was first identified in Argentina in 1923, and the disease symptoms were observed in lemon and orange; CBC type $C$ is restricted to the São Paulo state in Brazil, and it infects Mexican limes [7]. Because the symptoms of the three CBC types are almost similar, the disease type is only distinguishable by examining the phenotypic and genotypic characteristics of the Xanthomonas strains [4].

The genus Xanthomonas (family Xanthomonadaceae) is composed of 27 species, which collectively cause serious diseases in $\approx 400$ plant species, including citrus, rice, tomato, cabbage, and bean [9]. During the infection process, Xanthomonas enters the host through the hydathodes or wounds, and it colonizes and multiplies in the mesophyll parenchyma and apoplastic regions of the host [9]. The virulence factors encoded by Xanthomonas include secretion systems (i.e., type III secretion system genes), effectors, cell-wall degrading enzymes (i.e., pectate lyase, polygalacturonase), toxins, and bacterial adhesins, which collectively cause tissue maceration, electrolyte loss, and cell death in the host plant [10].

$\mathrm{CBC}$ is characterized by the development of small necrotic lesions on the lower surface of the leaf that expand over time because of hyperplasia (an increase in the number of cells) and hypertrophy (enlargement of an organ) [11]. With time, the lesions become brown with oily water-soaked margins usually surrounded by a yellow chlorotic halo that become visible on the upper surface of the leaf. Lesions on young stems and fruits are generally raised and corky and sometimes open like a blister or volcano (erumpent) $[5,12]$. In a susceptible citrus host, the disease caused by Xanthomonas results in defoliation, premature fruit abscission, and shoot dieback, triggering a significant decrease in the crop yield and fruit marketability [4]. CBC is mostly transmitted through contaminated seeds, soils, insects, and possibly agricultural practices [9]. In addition, an orchard in Florida produced the first documented evidence of $\mathrm{CBC}$ spreading over longer distances because of high winds and heavy rainfall during a thunderstorm in $1990[4,13]$.

For many years, the most common approaches to control $\mathrm{CBC}$ were the eradication of symptomatic citrus trees to prevent the spread of the pathogens [4]. However, some citrus producers rely on less susceptible cultivars planted in Xanthomonas-free nurseries. Spraying of copper-based bactericides (i.e., copper hydroxide, copper oxychloride, and copper oxide) has been used for more than two decades to control CBC [11]. Unfortunately, frequent use of these bactericides to control the pathogenic strains of Xanthomonas spp. has led to the development of copper-resistant strains [14,15]. Besides, copper-based bactericides leave copper residuals on the plants and cultivated soils, with potential phytotoxic and adverse environmental effects that eventually lead to an increase in the cost of production [16]. Streptomycin sulfate is most widely used to control CBC caused by Xanthomonas [17]. In addition to the advent of streptomycin-resistant strains due to the frequent spraying of streptomycin, streptomycin has been banned by European authorities because of the risks associated with the development of antibiotic resistance in non-target microbes [18]. CBC continues to spread, and approximately 12 million USD is spent on the control of $C B C$ every year [12]; there is a pressing need to find alternative methods to control CBC.

Recently, endophytic microorganisms as biocontrol agents are gaining attention over chemical bactericides regarding the control of plant diseases $[19,20]$. Endophytes are preferred for controlling pathogenic microbes because they are environment-friendly and versatile in their mode of action [21,22]. Nearly 300,000 plant species exist on Earth, and each of them is the host of one or more endophytes [23]. The term "endophyte" was first coined by De Bary in 1866, and he defined endophytes as a group of microorganisms, often bacteria or fungi, that colonize intracellular locations of healthy plants without displaying any external sign of infection in the host [24,25]. However, some bacteria classified as endophytes seem to act as latent pathogens that participate in host plant infection under favorable conditions [26]. Endophytic microorganisms can promote plant growth, defense, and disease resistance by synthesizing antimicrobial molecules and phytohormones or activating host plant immunity through induced systemic resistance (ISR) and systemic acquired resistance (SAR) [20,27]. 
Several Bacillus spp., in particular, B. subtilis, B. amyloliquefaciens FZB42, B. amyloliquefaciens subsp. plantarum, B. methylotrophicus, B. oryzicola, and B. velezensis, have been reported for their biocontrol ability against a wide range of phytopathogenic microorganisms, for example, $X$. oryzae pv. oryzae and X. oryzae pv. oryzicola [28], Erwinia amylovora [18], Botrytis cinerea [29], Acidovorax oryzae [30], Rhizoctonia solani [31], Ralstonia solanacearum [27], and Fusarium graminearum [32]. Bacillus-based products are now commercially available, for example, RhizoVital ${ }^{\circledR}$ (B. amyloliquefaciens FZB42; ABiTEP, GmbH, Berlin, Germany), Amylo- $X^{\circledR}$ WG (B. amyloliquefaciens subsp. plantarum D747; Certis Europe BV, Netherlands), RhizoPlus $^{\circledR}$ (B. subtilis FZB24; ABiTEP), Sonata ${ }^{\circledR}$ (B. pumilus QST2808; AgraQuest, Inc., Davis, CA, USA), and Taegro ${ }^{\circledR}$ (B. subtilis var. amyloliquefaciens FZB24; Novozymes Biologicals, Inc., Salem, VA, USA) [33].

Recent phylogenomic studies based on RNA polymerase beta-subunit (rpoB) gene sequences and core genome sequences of bacterial strains suggested that $B$. velezensis is synonymous with B. amyloliquefaciens subsp. plantarum, B. amyloliquefaciens FZB42, B. methylotrophicus, and B. oryzicola [34-36]. B. velezensis is considered a microbial factory for the production of diverse biologically active secondary metabolites, such as cyclic lipopeptides (i.e., surfactin, bacillomycin-D, fengycin, and bacillibactin) and polyketide molecules (i.e., macrolactin, bacillaene, and difficidin) synthesized by modularly organized mega-enzymes, known as non-ribosomal peptide synthetases and polyketide synthases, respectively [21,32]. Besides, this bacterium is capable of synthesizing bacilysin, a non-ribosomally synthesized dipeptide antibiotic, and ribosomally synthesized modified peptide antibiotics plantazolicin (bactericidal and nematicidal molecules) [37] and amylocyclicin (bactericidal) [38].

In this study, we searched for effective endophytic bacteria from different Citrus spp. to control Xcc. We isolated an endophytic $B$. velezensis that can control the wild type and even streptomycin-resistant $X c c$ strains. To our knowledge, this is the first report of $B$. velezensis displaying an antibacterial effect against Xcc pathogens that cause $\mathrm{CBC}$.

\section{Materials and Methods}

\subsection{Plant Materials}

Nine 3-year-old Citrus spp. (Table 1) were purchased from the Jeju Hanla Farm (Jeju, Republic of Korea), planted in pots $(18 \mathrm{~cm} \times 20 \mathrm{~cm})$, and grown under greenhouse conditions. Fully expanded fresh leaves were collected for the isolation of endophytic bacteria. The leaves of Hwanggeum hyang, which is susceptible to $C B C$, were used for pathogen infection experiments in a detached leaf assay.

\subsection{Bacterial Strains and Growth Conditions}

Endophytic bacteria isolated from Citrus spp. were routinely grown on yeast-extract nutrient agar (YNA; $5 \mathrm{~g}$ yeast extract, $8 \mathrm{~g}$ nutrient broth, and $15 \mathrm{~g}$ agar per liter). These isolates were used for the antibacterial assay against nine Xcc pathogens: three were wild type (XccW1 (Xcc 19-18), XccW2 (Xcc 10-5), and XccW3 (Xcc 53-4)) and six were streptomycin-resistant mutants (XccM4 (Xcc 27-9), XccM5 (Xcc 8-4), XccM6 (Xcc 57-2), XccM7 (Xcc 57-5), XccM8 (Xcc 27-13), and XccM9 (Xcc 27-12)) [39]. All these strains were kindly provided by Dr. Hyun of the Citrus Research Station (NIHH, RDA, Jeju, Republic of Korea). The wild-type Xcc strains were grown in YNA, and the mutant streptomycin-resistant Xcc strains were grown in YNA with $50 \mathrm{mg} \mathrm{mL}^{-1}$ streptomycin for selective growth. For long-term storage, the bacterial cultures were maintained at $-80^{\circ} \mathrm{C}$ in $\mathrm{YNB}(5 \mathrm{~g}$ yeast extract and $8 \mathrm{~g}$ nutrient broth per liter) with $35 \%$ glycerol.

\subsection{Isolation of Endophytic Bacteria}

The endophytic bacteria were isolated according to previously described standard procedures [40]. Briefly, healthy and disease-free leaves were collected from the plants and washed thoroughly with sterile distilled water (SDW) to remove adherent soil particles and microbes. The samples were then 
dried with tissue paper, weighed with a digital balance, and surface-sterilized with $70 \%$ ethanol for $1 \mathrm{~min}, 2 \%$ sodium hypochlorite $(\mathrm{NaOCl}$ ) solution for $3 \mathrm{~min}$, and $100 \%$ ethanol for $30 \mathrm{~s}$. The samples were washed three times with SDW and dried using sterilized filter paper. The surface-sterilized samples were ground to a slurry with a sterilized mortar and pestle in the ratio of $1 \mathrm{gm}$ fresh weight per $3 \mathrm{~mL} \mathrm{NaCl}$ solution $(0.9 \%)$. The tissue extracts were then incubated for $3 \mathrm{~h}$ at $28^{\circ} \mathrm{C}$ for the complete release of the endophytic bacteria, homogenized, and serially diluted up to $10^{-2}$ with sterilized $\mathrm{NaCl}$ solution $(0.9 \%)$. For each dilution, $50 \mu \mathrm{L}$ suspensions were spread on $25 \%$ YNA ( $1.25 \mathrm{~g}$ yeast extract, $2 \mathrm{~g}$ nutrient broth, and $15 \mathrm{~g}$ agar per liter) with a stainless-steel spreader and incubated at $28{ }^{\circ} \mathrm{C}$ for 15 days. The colonies with a different morphology and color were selected and purified by sub-culture under aseptic conditions. The morphological characteristics of the isolated strains, such as form, margin, color, and elevation of the colonies, were recorded. A total of 66 endophytic bacteria were obtained from the nine Citrus spp. (Table 1).

\subsection{Primary Screening of the Antagonistic Bacterial Isolates Against Xcc}

All the endophytic bacterial isolates were screened for their antibacterial activity against the $\mathrm{XccW1}$ strain, according to a previously described method [41] with minor modifications. Briefly, all 66 isolates were cultured in 96-well microtiter plates containing $190 \mu \mathrm{L}$ YNB and $10 \mu \mathrm{L}$ individual bacterial strains and incubated in a rotary shaker for $48 \mathrm{~h}$ at $28^{\circ} \mathrm{C}$ and $100 \mathrm{rpm}$. Subsequently, $10 \mu \mathrm{L}$ individual isolates were transferred onto square plates containing YNA and incubated for $36 \mathrm{~h}$ at $28^{\circ} \mathrm{C}$. The patches of endophytic bacteria grown on the square plates were killed with chloroform; subsequently; the plates were uncovered for $20 \mathrm{~min}$ to remove any traces of the chloroform residue. The petri plates were then exposed to UV radiation for $15 \mathrm{~min}$. Finally, the plates were overlaid with $10 \mathrm{~mL}$ soft agar $(0.75 \%$ agar in YNA) pre-inoculated with a $25 \mu \mathrm{L} \mathrm{XccW1}$ strain grown overnight. After further incubation at $28^{\circ} \mathrm{C}$ for $24 \mathrm{~h}$, the overlaid plates were checked for any zones of inhibition against the test pathogen. The diameters of the zones of inhibition were measured using an electronic digital caliper. Based on the activity against XccW1, the isolates were subjected to further analysis against the three wild-type and six streptomycin-resistant strains of Xcc.

\subsection{Phylogenetic Analyses of $16 S$ rRNA Gene Sequences}

Out of the 66 isolates, three endophytic bacterial isolates (EB-35, EB-39, and EB-44) exhibited antibacterial activity against Xcc strains. These isolates were identified using $16 \mathrm{~S}$ rRNA sequence analysis. The 16S rRNA sequences were compared using Basic Local Alignment Search Tool (BLAST) in the National Center for Biotechnology Information (NCBI) database. The phylogenetic analysis was performed using the neighbor-joining method in the MEGA program (https://www.megasoftware.net/). The phylogenetic tree was inferred from the type strains of the species related to Bacillus spp. (Figure 1 and Figure S1). Bootstrap replication (1000) was used to statistically analyze the nodes in the phylogenetic tree.

\subsection{Antagonistic Activities of Ethyl Acetate Extracts of the Endophytic Bacteria Against Xcc}

Metabolites were extracted according to a previously described procedure [42]. Ethyl acetate was selected for the metabolite extraction process because of its low boiling point and moderate polarity. The seed cultures (5 mL YNB) of EB-35, EB-39, and EB-44 were transferred to $200 \mathrm{~mL}$ YNB in $0.5 \mathrm{~L}$ Erlenmeyer flasks, cultured in a rotary shaker at $180 \mathrm{rpm}$ and $28^{\circ} \mathrm{C}$, and allowed to grow for $36-48 \mathrm{~h}$ until the $\mathrm{OD}_{600 \mathrm{~nm}}$ reached 1 . An equal volume of ethyl acetate was added to the bacterial cultures, and the flasks were sonicated for $5 \mathrm{~min}$ and maintained overnight with vigorous shaking. The culture broth was centrifuged at $3500 \mathrm{rpm}$ for $15 \mathrm{~min}$ at $4{ }^{\circ} \mathrm{C}$, and the supernatant was collected and dried in a rotary evaporator (A-1000S; Eyela, Tokyo, Japan) at $50^{\circ} \mathrm{C}$. The residues were dissolved in $0.5 \mathrm{~mL}$ High-Performance Liquid Chromatography (HPLC) grade methanol, collected in tubular glass vials, and air-dried under a chemical hood. The antibiotic assay was performed by dissolving the extracts in methanol to a concentration of $100 \mathrm{mg} \mathrm{mL}^{-1}$, and $30 \mu \mathrm{L}$ of the solution was used for the agar well 
diffusion assay. The antagonistic activities of the isolates against the Xcc strains were determined using the diameter of the inhibition zone.

\subsection{Determination of the Minimum Inhibitory Concentration and Minimum Bactericidal Concentration}

The minimum inhibitory concentration (MIC) and minimum bactericidal concentration (MBC) of the streptomycin and ethyl acetate extracts of EB-39 were determined using the broth micro-dilution method [43]. Various dilutions of the ethyl acetate extract of EB-39, from 23.4-1500 $\mu \mathrm{g} \mathrm{mL}^{-1}$, were prepared for the MIC analysis. The streptomycin concentrations ranged from $1.95-125 \mu \mathrm{g} \mathrm{mL}^{-1}$ to 46.87-3000 $\mu \mathrm{g} \mathrm{mL}^{-1}$ against the wild-type and streptomycin-resistant Xcc strains, respectively. In 96-well microtiter plates, $100 \mu \mathrm{L}$ of the ethyl acetate extract was added to a mixture of $90 \mu \mathrm{L}$ YNB and $10 \mu \mathrm{L}$ Xcc (standardized to $\approx 2.2 \times 10^{4} \mathrm{CFU} /$ well). The positive control consisted of $190 \mu \mathrm{L}$ YNB and $10 \mu \mathrm{L}$ Xcc, and the negative control had $200 \mu \mathrm{L}$ YNB broth without the addition of Xcc. The plates were incubated at 28 ${ }^{\circ} \mathrm{C}$ for $24 \mathrm{~h}$. MIC was recorded as the lowest concentration of the ethyl acetate extract or streptomycin that prevented visible growth of the Xcc. For MBC determination, $10 \mu \mathrm{L}$ of the MIC cultures from the microtiter plates were transferred onto YNA plates and incubated at $28^{\circ} \mathrm{C}$ for $24 \mathrm{~h}$. The lowest concentrations of the ethyl acetate extract and streptomycin that prevented visible growth of the bacteria on the YNA plates were indicated as the MBCs. Both MIC and MBC were expressed in $\mu \mathrm{g} \mathrm{mL}{ }^{-1}$.

\subsection{Scanning Electron Microscopy Analysis}

Scanning electron microscopy (SEM) analysis was performed to determine the effects of the ethyl acetate extract of EB-39, as well as streptomycin on XccW1, XccM4, and XccM5 cells. Xcc strains treated with methanol were used as the control. For the SEM observation, both wild-type and streptomycin-resistant Xcc strains $\left(\approx 3.2 \times 10^{4} \mathrm{CFU} \mathrm{mL}{ }^{-1}\right)$ were treated with the MIC of the ethyl acetate extract of EB-39 and streptomycin for $12 \mathrm{~h}$ at $28^{\circ} \mathrm{C}$. The suspension was centrifuged at $6000 \mathrm{rpm}$ for $5 \mathrm{~min}$, and the supernatant was discarded. The pellet was further washed five times with $1 \mathrm{~mL}$ phosphate buffer $(0.1 \mathrm{M})$ at $\mathrm{pH}$ 7.4. Subsequently, $10 \mu \mathrm{L}$ of the bacterial pellet was placed in poly-L-lysine-coated glass slides and pre-fixed overnight with $2.5 \%$ glutaraldehyde solution at 4 ${ }^{\circ} \mathrm{C}$. The fixed cells were rinsed five times for $10 \mathrm{~min}$ with a $0.1 \mathrm{M}$ phosphate buffer, post-fixed for 3 $\mathrm{h}$ in $2 \%$ osmium tetroxide, and washed three times with SDW to remove traces of salt crystals from the phosphate buffer. Finally, the cells were dehydrated in a graded ethanol series $(50 \%, 70 \%, 80 \%$, $85 \%, 90 \%$, and $100 \%$ ) for $15 \mathrm{~min}$. The samples were mounted on copper grids, sputter-coated with platinum, and examined with a Hitachi S- 4800 scanning electron microscope (Hitachi, Tokyo, Japan) at an accelerating voltage of $15.0 \mathrm{kV}$ under standard operating conditions [28,44].

\subsection{Testing the Pathogenicity and Disease Suppression Ability of EB-39}

Pathogenic wild-type $\mathrm{XccW} 2$ were grown overnight at $28^{\circ} \mathrm{C}$ in $\mathrm{YNB}$ and centrifuged at $3500 \mathrm{rpm}$ for $15 \mathrm{~min}$. The pellet was resuspended in SDW and adjusted to a concentration of $0.4 \mathrm{OD}_{600 \mathrm{~nm}}$ that was determined with a nanodrop (ASP-3700; ACTGene, Piscataway, NJ, USA). For the detached leaf assay, fully expanded and immature (four-week-old) leaves were excised from the Hwanggeum hyang cultivar (highly canker-susceptible), generated from a cross between C. unshiu $\times$ C. sinensis and C. unshiu. The leaves were washed with SDW and subjected to infiltration by pushing a needleless syringe against the surface of the citrus leaf supported by a finger on the opposite side of the leaf. For each treatment, a $0.1 \mathrm{~mL}$ suspension was used to infiltrate the citrus leaves. The freshly detached leaves of Hwanggeum hyang were inoculated with SDW (negative control), $\mathrm{XccW} 2$ at $0.4 \mathrm{OD}_{600 \mathrm{~nm}}$ (positive control), and a mixture of XccW2:EB-39 at $0.4 \mathrm{OD}_{600 \mathrm{~nm}}$ and EB-39 at $0.4 \mathrm{OD}_{600 \mathrm{~nm}}$. The mixture was prepared by mixing equal volumes of $X c c W 2$ at $0.8 \mathrm{OD}_{600 \mathrm{~nm}}$ and EB-39 at $0.8 \mathrm{OD}_{600 \mathrm{~nm}}$. The inoculated plant leaves were maintained in a humid box with three layers of sterile tissue paper moistened with SDW and incubated in a growth chamber at $28{ }^{\circ} \mathrm{C}$. The severity of the disease symptoms on the Hwanggeum hyang leaves were scored in triplicate 7 days post-infection [12,45]. 


\section{Results}

3.1. Primary Screening of the Endophytic Bacteria Isolated from Citrus spp.

A total of 66 endophytic bacterial strains were isolated from nine different Citrus spp. (Table 1). The morphological characteristics of the isolated EB were documented on the basis of colony color, form, elevation, and margin.

Table 1. List of endophytic bacteria isolated from Citrus spp.

\begin{tabular}{cclc}
\hline Serial No. & Citrus Species & Tissue & Number of Isolates \\
\hline 1 & Summer mandarin & Leaves & 5 \\
2 & Yakeum mandarin & Leaves & 2 \\
3 & Navel orange & Leaves & 6 \\
4 & Leeyegam mandarin & Leaves & 4 \\
5 & Manbeckyu mandarin & Leaves & 4 \\
6 & Early season citrus & Leaves & 6 \\
7 & Palsak mandarin & Leaves & 11 \\
8 & Dangyuja mandarin & Leaves & 4 \\
9 & Hwangkeum hyang & Leaves & 24 \\
\hline \multicolumn{3}{c}{ Number of total isolates } \\
\hline
\end{tabular}

All the isolates were screened for their antagonistic effects against XccW1 by using the agar overlay method [41]. The top three bacterial strains with antibacterial activity were EB-35, EB-39, and EB-44, isolated from Palsak mandarin, Dangyuja mandarin, and Hwangkeum hyang Citrus spp., respectively. The largest inhibition zone against XccW1 was formed by EB-39, followed by EB-44 and EB-35 (Table 2). The BLAST homology analysis revealed that the 16S rRNA gene sequences of the three bacteria belong to the genus Bacillus. In addition, the phylogenetic tree inferred from the 16S rRNA gene sequences indicated that the isolates EB-35, EB-39, and EB-44 share a high degree of identity with B. wiedmannii, B. velezensis, and B. toyonensis, respectively (Figure 1 and Figure S1).

Table 2. Primary screening of endophytic bacteria by XccW1.

\begin{tabular}{cccccc}
\hline Isolates & Species & Max Score & E. Value & Max Identity (\%) & Zone of Inhibition (mm) * \\
\hline EB-35 & B. wiedmannii & 2074 & 0.0 & 99.74 & 18.2 \\
EB-39 & B. velezensis & 2368 & 0.0 & 99.92 & 36.7 \\
EB-44 & B. toyonensis & 2636 & 0.0 & 99.59 & 18.5 \\
\hline
\end{tabular}

* Diameter of the inhibition zones.

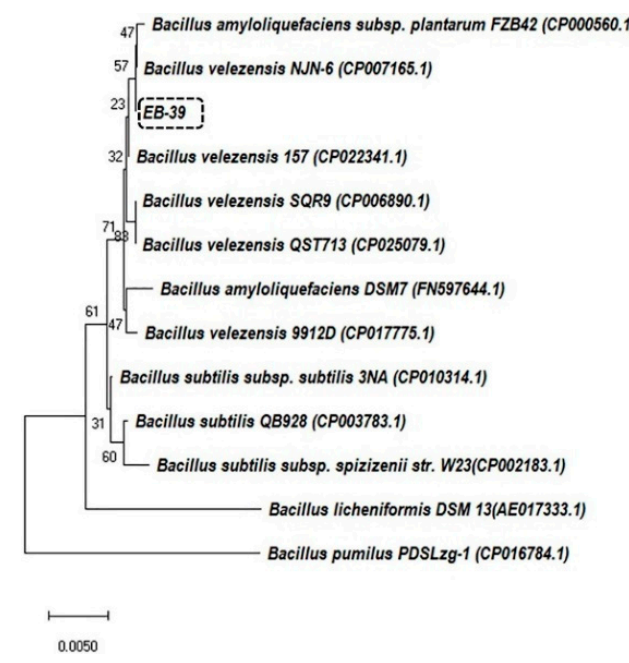

Figure 1. Phylogenetic tree based on the 16S rRNA gene sequences that highlights the position of EB-39 relative to the other strain types within the genus Bacillus. Accession numbers retrieved from the NCBI 
database are provided within parentheses. Bootstrap values (\%) are mentioned at the nodes and obtained by repeating the analysis 1000 times. The scale bar indicates 0.005 nucleotide substitutions per nucleotide position.

\subsection{Antibacterial Activity of the Live Endophytic Bacteria Against Xcc}

The three identified strains were further challenged with all three wild-type and six mutant strains of Xcc for a comparison of the antibacterial activities (Figure 2A,B). EB-39 exhibited the highest antibacterial effect against all the Xcc strains, with the inhibition zones ranging from $39.47 \pm 1.6$ to $45.31 \pm 1.6 \mathrm{~mm}$. EB-35 and EB-44 also exhibited antagonistic effects against all wild-type and mutant strains; however, their antibacterial activities were lower than that of EB-39. The inhibition zones of EB-35 and EB-44 ranged from $20.13 \pm 0.1$ to $23.5 \pm 0.5 \mathrm{~mm}$ and $20.28 \pm 0.2$ to $22.78 \pm 0.8 \mathrm{~mm}$, respectively (Figure 2A,B).

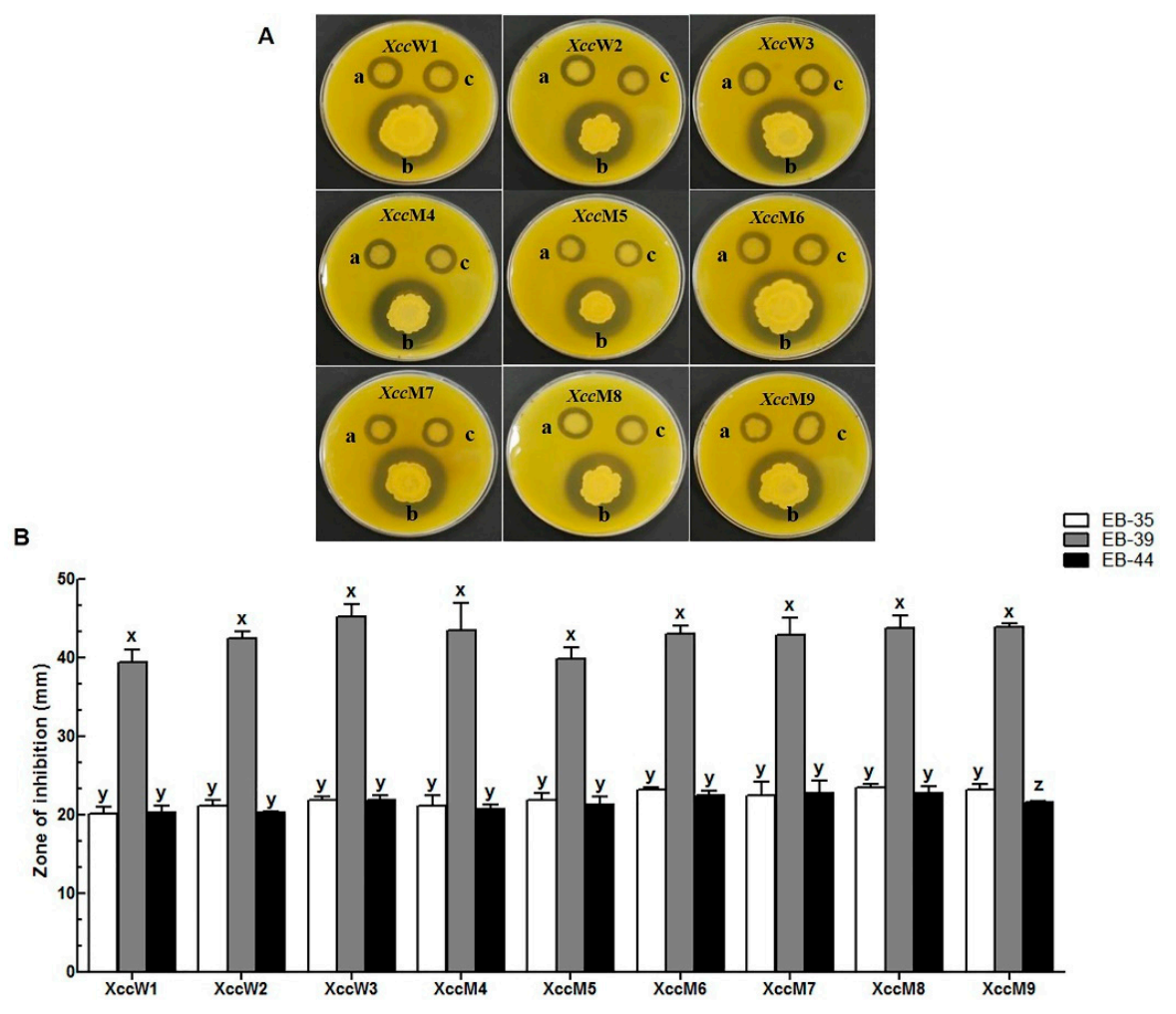

Figure 2. In vitro antagonistic activity of endophytic bacteria against X. citri subsp. citri. (A) The test was conducted using the pathogenic strains XccW1-XccW3 (wild-type strains) and XccM4-XccM9 (streptomycin-resistant mutant strains). a: EB-35 (B. wiedmannii); b: EB-39 (B. velezensis); c: EB-44 (B. toyonensis). (B) Antagonistic activity of the endophytic bacteria was measured using the wild-type and streptomycin-resistant X. citri subsp. citri strains. Different letters on bars indicate significant differences at $p<0.05$ using Duncan's test.

\subsection{Antagonistic Effects of the Ethyl Acetate Extracts of the Endophytic Bacteria on Xcc}

The three endophytic bacteria were further tested for the antibacterial effects of their ethyl acetate extracts on all Xcc strains. EB-39 was found to have active secondary metabolites that showed strong antibacterial activity against both wild-type and mutant Xcc strains, with the zone of inhibition ranging from $29.28 \pm 0.6$ to $33.88 \pm 1.3 \mathrm{~mm}$ (Figure S2). The ethyl acetate extracts of EB-35 and EB-44 did not display any antagonistic effects against the Xcc strains.

The antibacterial activity of the ethyl acetate extract of EB-39 $\left(100 \mathrm{mg} \mathrm{mL}^{-1}\right)$ was further compared with those of two streptomycin concentrations (S1: streptomycin $\left(50 \mathrm{mg} \mathrm{mL}^{-1}\right)$ and S2: streptomycin 
$\left.\left(5 \mathrm{mg} \mathrm{mL} \mathrm{m}^{-1}\right)\right)$. The ethyl acetate extract of EB-39 had an antibacterial effect on both wild-type and streptomycin-resistant $X c c$ strains, with the zone of inhibition ranging from $29.82 \pm 1.1$ to $32.20 \pm 2.9 \mathrm{~mm}$ (Figure 3A,B). S1 and S2 had antagonistic effects on the wild-type Xcc strains, with the zone of inhibition ranging from $40.96 \pm 1.38$ to $43.79 \pm 1.05 \mathrm{~mm}$ and $32.11 \pm 0.35$ to $34.60 \pm 0.0 \mathrm{~mm}$, respectively. However, S1 exhibited a significantly reduced antibacterial effect on the streptomycin-resistant Xcc strains, with the zone of inhibition ranging from $10.5 \pm 0.6$ to $12.9 \pm 2.3 \mathrm{~mm}$; S2 did not have any antibacterial effect on the streptomycin-resistant Xcc strains (Figure 3A,B). We compared the antibacterial activity of EB-39 with a standard B. velezensis (KACC no. 17177) obtained from the Rural Development Agriculture (RDA), Jeonju-si, Republic of Korea. Compared with the extract of the standard B. velezensis, that of our newly isolated B. velezensis EB-39 had $21.1 \%$ and $18.0 \%$ higher antibacterial activity against XccW1 and $\mathrm{XccM} 4$ using $1 \mathrm{mg}$ of ethyl acetate extract $\mathrm{mL}^{-1}$, respectively (Figure $3 \mathrm{C}$ ).

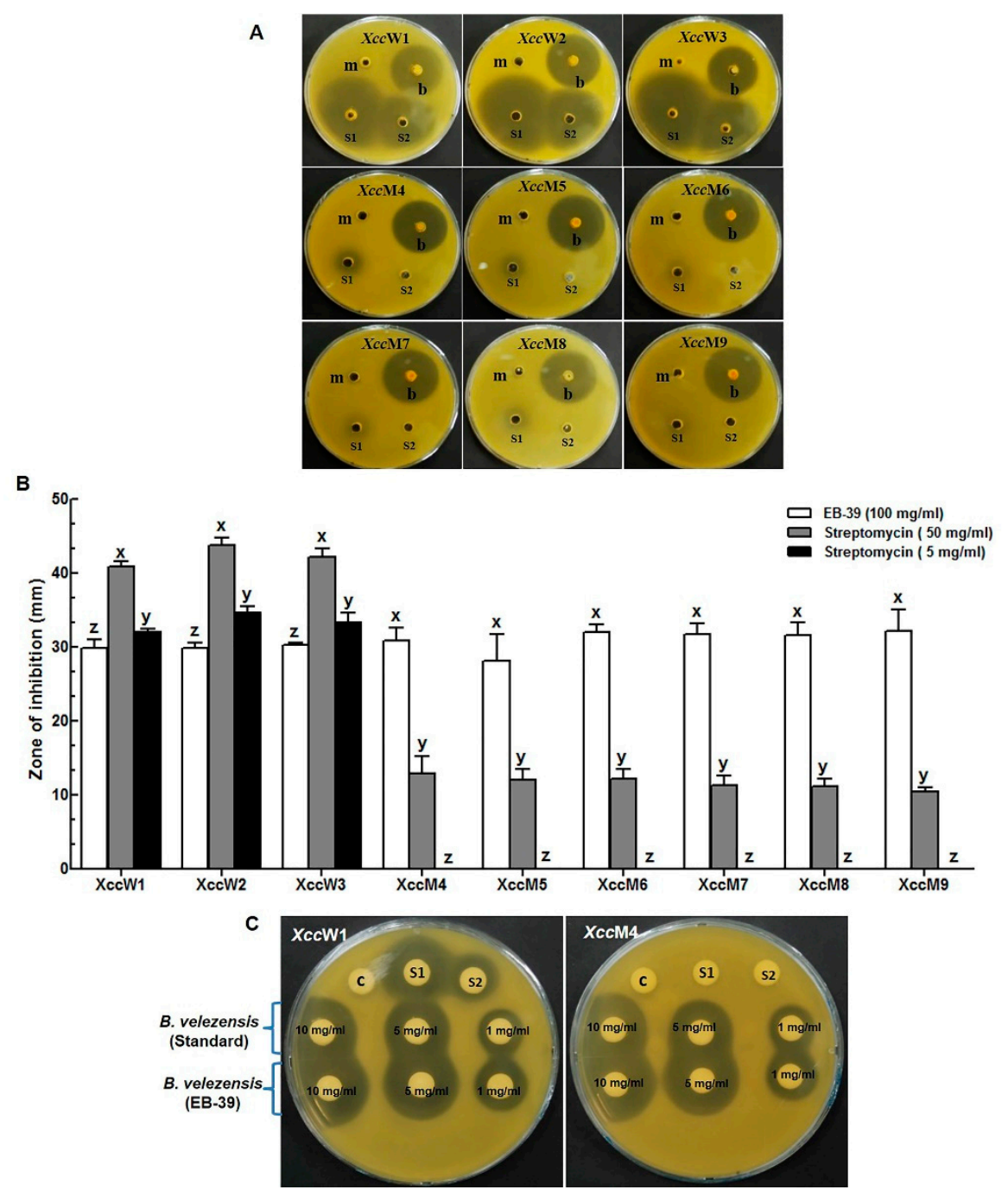

Figure 3. Comparison of the antibacterial effects of the ethyl acetate extract of B. velezensis (EB-39) and streptomycin on the wild-type and streptomycin-resistant X. citri subsp. citri strains. (A) The antibacterial activity was measured using the agar well diffusion assay. XccW1-XccW3 (wild-type strains) and XccM4-XccM9 (streptomycin-resistant mutants). m: methanol control; b: ethyl acetate extract of EB-39 (100 mg mL $\left.{ }^{-1}\right)$; S1: streptomycin $\left(50 \mathrm{mg} \mathrm{mL}^{-1}\right)$; S2: streptomycin $\left(5 \mathrm{mg} \mathrm{mL}^{-1}\right)$. (B) Antagonistic activity of the ethyl acetate extracts of the endophytic bacteria was measured against the wild-type and streptomycin-resistant $X$. citri subsp. citri strains. Different letters on bars indicate significant differences at $p<0.05$ using Duncan's test. (C) Comparison of antibacterial effects of the ethyl acetate extract of the standard B. velezensis (KACC no. 17,177) and our newly isolated B. velezensis 
(EB-39). c: methanol control; S1: streptomycin ( $\left.0.5 \mathrm{mg} \mathrm{mL}^{-1}\right)$; S2: streptomycin $\left(0.1 \mathrm{mg} \mathrm{mL}^{-1}\right)$; Ethyl acetate extract of the standard and EB-39 B. velezensis $\left(10,5\right.$, and $\left.1 \mathrm{mg} \mathrm{mL}^{-1}\right)$.

\subsection{Determination of MIC and MBC}

Among the antagonistic endophytic bacterial strains, EB-39 had the highest antibacterial activity against all Xcc strains and was therefore selected for the determination of MIC and MBC. The MIC and MBC values of EB-39 were 46.8-93.7 $\mu \mathrm{g} \mathrm{mL}^{-1}$ and $93.7-187.5 \mu \mathrm{g} \mathrm{mL}^{-1}$, respectively (Table 3). In contrast, the MIC of streptomycin against the wild-type Xcc strains was considerably lower $\left(1.95 \mu \mathrm{g} \mathrm{mL}^{-1}\right)$ than that against the mutant Xcc strains $\left(370-755 \mu \mathrm{g} \mathrm{mL} \mathrm{L}^{-1}\right)$. The MBC of streptomycin against the Xcc strains was 3.9-750 $\mu \mathrm{g} \mathrm{mL}^{-1}$ (Figures S3 and S4, Table 3).

Table 3. MIC and MBC values of the ethyl acetate extract of $B$. velezensis and streptomycin against $X$. citri subsp. citri (Xcc) on YNA plates.

\begin{tabular}{ccccc}
\hline \multirow{2}{*}{ Xcc Strains } & \multicolumn{2}{c}{ Ethyl Acetate Extracts of B. velezensis } & \multicolumn{2}{c}{ Streptomycin } \\
\cline { 2 - 5 } & $\mathbf{M I C}\left(\boldsymbol{\mu g} \mathbf{~ m L}^{-\mathbf{1}}\right)$ & $\mathbf{M B C}\left(\boldsymbol{\mu g} \mathbf{~ m L}^{-\mathbf{1}}\right)$ & $\mathbf{M I C}\left(\boldsymbol{\mu g} \mathbf{~ m L}^{-\mathbf{1}}\right)$ & $\mathbf{M B C}\left(\boldsymbol{\mu g} \mathbf{~ m L}^{-\mathbf{1}}\right)$ \\
\hline XccW1 & 93.7 & 187.5 & 1.95 & 3.90 \\
XccW2 & 93.7 & 187.5 & 1.95 & 3.90 \\
XccW3 & 46.8 & 93.7 & 1.95 & 3.90 \\
XccM4 & 46.8 & 93.7 & 375.0 & 750.0 \\
XccM5 & 93.7 & 187.5 & 375.0 & 750.0 \\
XccM6 & 93.7 & 187.5 & 375.0 & 750.0 \\
XccM7 & 46.8 & 93.7 & 375.0 & 750.0 \\
XccM8 & 93.7 & 187.5 & 750.0 & 1500.0 \\
XccM9 & 46.8 & 93.7 & 375.0 & 750.0 \\
\hline
\end{tabular}

\subsection{SEM Analysis of the B. velezensis Extract (EB-39)}

The SEM analysis was performed to visualize the cellular damage caused by the ethyl acetate extract of EB-39 and streptomycin on the Xcc strains (XccW1, XccM4, and XccM5; Figure 4). XccW1 was selected to represent the wild type, and XccM4 and XccM5 were selected to represent the streptomycin-resistant mutants on the basis of their genotypic classification. The control Xcc strains, as well as XccM4 and XccM5 treated with streptomycin, did not show any changes in morphology, and they had an intact rod shape with a smooth exterior. In contrast, all the Xcc strains (both the wild-type and streptomycin-resistant mutants), upon exposure to the ethyl acetate extract of EB-39, showed distortion of their normal rod structure, and cells eventually lysed. The same morphological changes were observed in the streptomycin-treated wild-type XccW1; however, the changes were not found in the mutant Xcc strains after the streptomycin treatment (Figure 4).

\subsection{Biocontrol Efficacy of the Antagonistic Endophytic Bacteria}

EB-39 was tested for biocontrol efficacy against XccW2. In the detached leaf assay, all citrus leaves were infiltrated with $0.1 \mathrm{~mL}$ distilled water, $\mathrm{XccW}$ 2, and a mixture of XccW2:EB-39 and EB-39 (Figure 5A,B). Seven days post-infiltration (dpi), both $\mathrm{XccW} 2$ and the $\mathrm{XccW}$ 2:EB-39 mixture generated canker lesions. However, the leaves infiltrated with the mixture of XccW2:EB-39 developed smaller infection lesions than those infiltrated with $\mathrm{XccW} 2$ alone (Figure 5A,B). The sizes of the necrotic lesions of XccW2 were significantly smaller than those of the mixture of XccW2:EB-39 (14.35 $\pm 0.45 \mathrm{~mm}$ vs. $8.27 \pm 0.47 \mathrm{~mm}$; Figure 5C). The lesions developed on the leaves infiltrated with XccW2 were visible on both surfaces and appeared in the form of water-soaked margins surrounded by yellow rings. The leaves infiltrated with EB-39, however, did not display any visible disease symptoms (Figure 5A,B). 


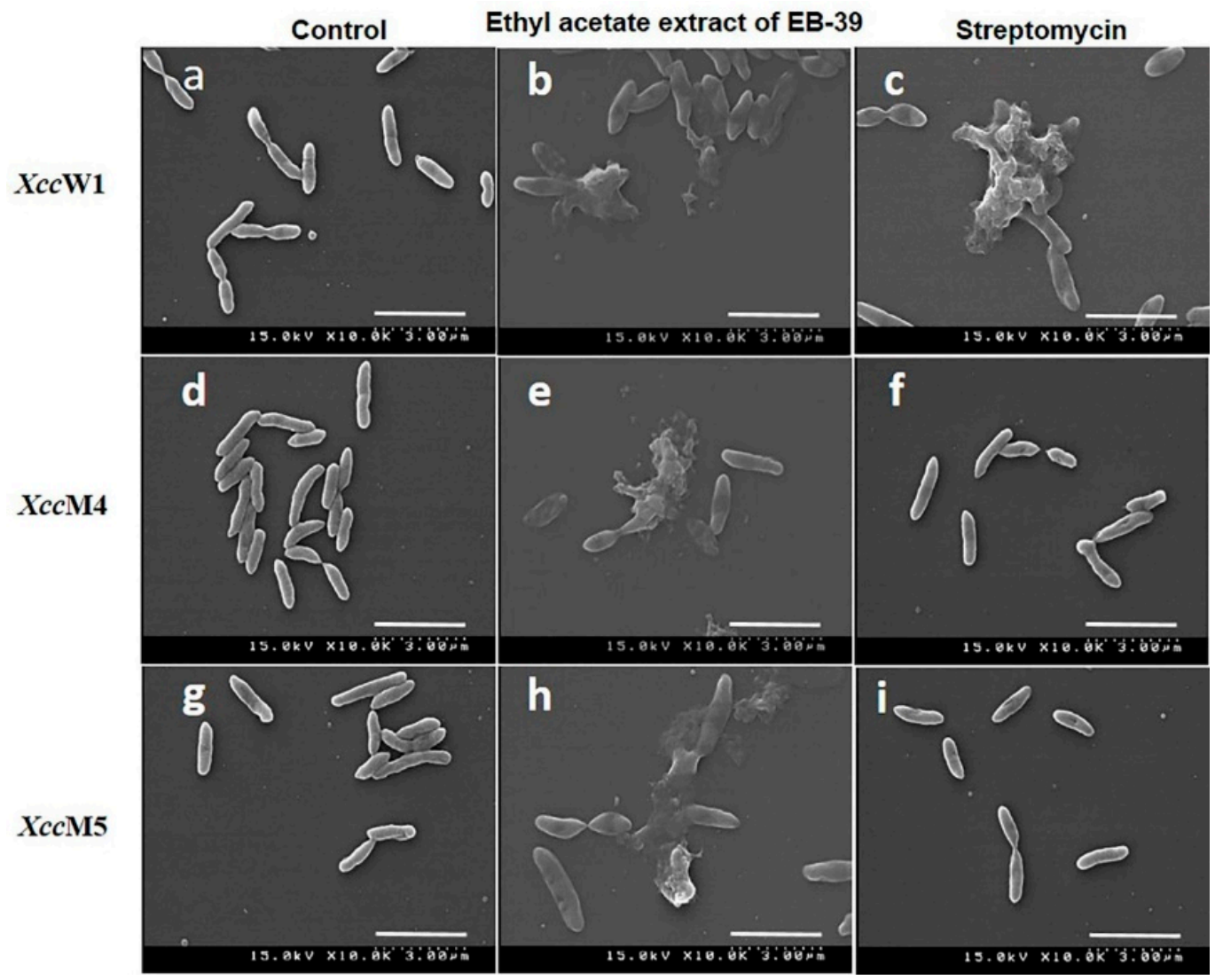

Figure 4. Scanning electron micrographs of Xcc strains treated with methanol as the negative control $(\mathbf{a}, \mathbf{d}, \mathbf{g})$; ethyl acetate extract of EB-39 (b,e,h); and streptomycin as the positive control $(\mathbf{c}, \mathbf{f}, \mathbf{i})$. The methanol-treated Xcc strains had a regular, uniform, and smooth surface. The EB-39-treated strains showed disruption, collapse, elongation, and cell lysis. The streptomycin-treated XccW1 cells were distorted and eventually lysed; however, the resistant Xcc strains (XccM4 and XccM5) had an intact, rod shape with a smooth surface. a-c: XccW1 treated with methanol (control), ethyl acetate extract of EB-39, and streptomycin; d-f: XccM4 treated with methanol (control), ethyl acetate extract of EB-39, and streptomycin; g-i: XccM5 treated with methanol (control), ethyl acetate extract of EB-39, and streptomycin. Scale bar: $3 \mu \mathrm{m}$.
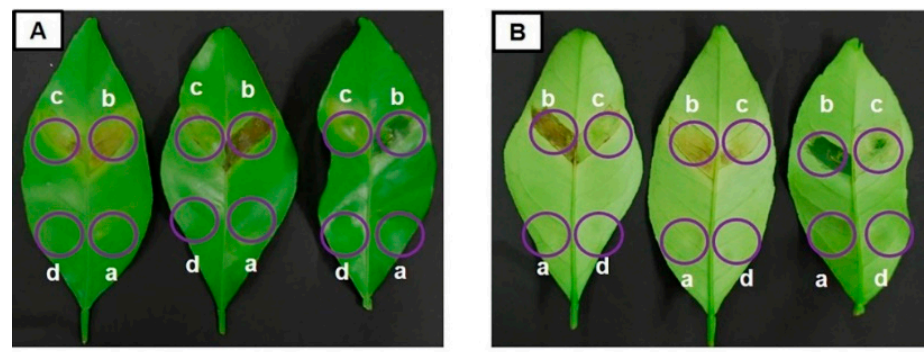

C

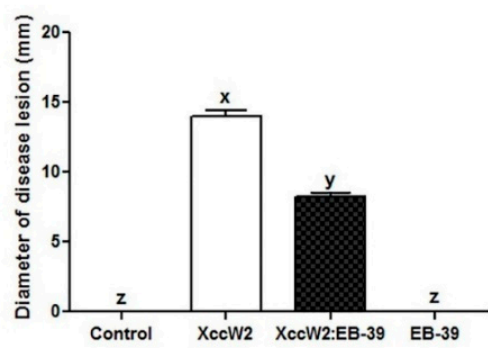

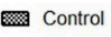

$\square$ XccW2

XccW2 EB-39

뗌 EB-39 (XccW2) on citrus leaves. (A) adaxial surface and (B) abaxial surface of the same leaves. In all cases, the 
leaves were infiltrated with $0.1 \mathrm{~mL}$ of (a) sterile distilled water, (b) XccW2, (c) XccW2 mixed with EB-39, and (d) EB-39. (C) Disease lesion diameter was measured at 7 dpi. The mean \pm standard deviation values from three independent replicates were calculated for each treatment. Different letters on bars indicate significant differences at $p<0.05$ using Duncan's test.

\section{Discussion}

$\mathrm{CBC}$ is one of the most destructive diseases in citrus plants in many production areas worldwide [5]. In the last few decades, citrus growers in many countries have been forced to eradicate millions of citrus plants because of the severity of CBC $[5,16]$. Treatment of the disease with copper-based chemical sprays and streptomycin has led to an increase in the number of resistant Xanthomonas strains [14,39]. The development of alternative biocontrol agents has now become a major challenge for scientists. Endophytic bacteria may play a significant role in controlling the disease [23].

In this study, a total of 66 endophytic bacteria were isolated from different varieties of Citrus spp. Among the isolated strains, three isolates exhibited in vitro inhibition of Xcc by forming inhibition zones (Figure 2A,B). The isolates were identified as Bacillus spp., namely, B. wiedmannii (EB-35), B. velezensis (EB-39), and B. toyonensis (EB-44) using 16S rRNA sequence analysis. To date, many strains of endophytic bacteria have been isolated from Citrus spp., for example, B. pumilus, B. megaterium, Enterobacter cloacae, Pantoea agglomerans, Pseudomonas aeruginosa, Burkholderia cepacia, and Curtobacterium flaccumfaciens $[40,46]$.

The solvent extracts of the selected strains were evaluated for their antibacterial activity against all the Xcc strains. The ethyl acetate extract of B. velezensis EB-39 exhibited the highest antibacterial activity against the wild-type and mutant strains of Xcc, and those of EB-35 and EB-44 did not show any antibacterial activity against the Xcc strains (Figure S2). In the comparative study of EB-39 metabolites and two different streptomycin concentrations, S1 $\left(50 \mathrm{mg} \mathrm{mL}^{-1}\right)$ and S2 $\left(5 \mathrm{mg} \mathrm{mL}^{-1}\right), \mathrm{S} 1$ and S2 displayed antagonistic effects against the wild-type Xcc strains. However, S1 had a significantly lower antibacterial effect against the mutant Xcc strains, whereas S2 had no effect on the mutant Xcc strains. These data strongly indicate that the ethyl acetate extract of EB-39 contained biologically active secondary metabolites that could suppress both wild-type and streptomycin-resistant mutant Xcc strains (Figure 3A,B).

SEM was used to detect the morphological changes caused by exposure to the ethyl acetate extracts in the Xcc strains. The SEM analysis indicated that the Xcc cells became distorted from their normal rod-shaped structure and eventually lysed because of treatment with the ethyl acetate extract of B. velezensis (Figure 4). The antimicrobial compounds possibly caused the Xcc cell membranes to destabilize, leading to leaking of the cell contents, leaving cell debris. Similar morphological deformities were observed in X. oryzae pv. oryzae cells exposed to $50 \mu \mathrm{g} \mathrm{mL}^{-1}$ difficidin or bacilysin isolated from $B$. amyloliquefaciens FZB42 (reclassified as a strain of B. velezensis) [28]. Although further research would be required to identify the antibacterial compounds, the ethyl acetate extract of $B$. velezensis should contain antibacterial compounds that induce lysis of Xcc.

The detached citrus leaves infiltrated with a bacterial mixture of XccW2:EB-39 significantly reduced the disease symptoms when compared with those infiltrated with XccW2; however, those infiltrated with EB-39 did not show any disease symptoms, indicating EB-39 is not a pathogen of citrus (Figure 5). Reductions in CBC severity and incidence have been observed in a Citrus spp. (Mexican lime) treated with the culture suspensions of B. amyloliquefaciens strains WG6-14 and B. subtilis TKS1-1 [47]. The disease severity of black pod rot of cacao caused by Phytophthora capsici was significantly reduced when detached cacao leaf disks were challenged with the bacterial endophyte B. cereus [48]. Several Bacillus spp., including B. subtilis, B. amyloliquefaciens, B. pumilus, B. thuringiensis, B. cereus, and B. sphaericus, reduced disease severity via the elicitation of ISR in diverse host plants such as tomato, sugar beet, watermelon, bell pepper, and cucumber [49]. Surfactin and other non-ribosomally synthesized 
secondary metabolites produced by B. amyloliquefaciens FZB42 enhanced the plant defense levels toward the bottom rot pathogen $R$. solani via the higher expression of plant defensin factor 1.2 (PDF 1.2) [50].

Overall, to the best of our knowledge, this is the first report of the control of $C B C$ by the endophyte B. velezensis isolated from Citrus spp. In a similar study, the methanolic extract of $B$. velezensis exhibited strong antagonistic activity against $R$. solanacearum, which infects many plant species such as potato (Solanum tuberosum), eggplant (Solanum melongena), and tomato (Solanum lycopersicum) [27]. B. velezensis is also known as a plant-associated bacterium with the ability to promote plant growth and produce different types of secondary metabolites that suppress phytopathogens [21,28]. The antibacterial activity of $B$. velezensis is mainly due to non-ribosomal synthesis of polyketides such as bacillaene, difficidin, and macrolactin $[21,38]$. B. velezensis showed the ability to suppress the growth of plant pathogenic bacteria, such as X. oryzae pv. oryzae and X. oryzae pv. oryzicola, the causative agents of bacterial blight and bacterial leaf streak of rice, respectively [28]. All the data strongly suggest that our newly isolated EB-39 is a novel antibacterial agent that can be used to control both wild-type and streptomycin-resistant mutant Xcc strains efficiently.

\section{Conclusions}

The isolated B. velezensis EB-39 exhibited antibacterial activity against wild-type and streptomycin-resistant Xcc pathogens. Therefore, EB-39 could be a practical and powerful biocontrol agent (either bacterial spray or extract) against CBC. Further studies are required for the identification of antibacterial compounds that control the streptomycin-resistant Xcc strains. Elucidation of the genes responsible for bioactive secondary metabolites and the expression control of the genes are additional important steps required for increasing the production of metabolites by $B$. velezensis.

Supplementary Materials: The following are available online at http://www.mdpi.com/2073-4395/9/8/470/s1, Figure S1: Phylogenetic tree based on the 16S rRNA gene sequences. (A). Highlighted position of EB-35 and (B). Highlighted position EB-44 relative to the other type strains within the genus Bacillus, Figure S2: (A). The ethyl acetate extracts of the Bacillus strains against the X. citri subsp. citri (Xcc) strains; m: methanol control a: EB-35 (B. wiedmannii); b: EB-39 (B. velezensis); c: EB-44 (B. toyonensis). (B). Antagonistic activity of the ethyl acetate extracts was measured against the wild-type and streptomycin-resistant X. citri subsp. citri strains, Figure S3: MIC and MBC values of the ethyl acetate extract of B. velezensis EB-39 against X. citri subsp. citri (Xcc) on YNA plates; $\mathrm{XccW} 1-\mathrm{XccW} 3$ (wild-type strains) and XccM4-XccM9 (streptomycin-resistant mutant strains), Figure S4: MIC and MBC values of the streptomycin against X. citri subsp. citri (Xcc) on YNA plates; XccW1-XccW3 (wild-type strains) and XccM4-XccM9 (streptomycin-resistant mutant strains).

Author Contributions: The experiments were performed by M.F.R. and M.S.A. The study was designed and the data interpreted by M.F.R. and K.-H.B. The manuscript was prepared by M.F.R., M.S.A., and K.-H.B.

Funding: This study was supported by the Basic Science Research Program through the National Research Foundation of Korea (NRF) funded by the Ministry of Education (NRF-2019R1F1A1052625).

Acknowledgments: The authors appreciate the research support provided by NRF.

Conflicts of Interest: The authors declare no conflict of interest.

\section{References}

1. Shi, Q.; Febres, V.J.; Jones, J.B.; Moore, G.A. A survey of FLS2 genes from multiple citrus species identifies candidates for enhancing disease resistance to Xanthomonas citri ssp. citri. Hortic. Res. 2016, 3, 1-11. [CrossRef] [PubMed]

2. USDA. Citrus: World Markets and Trade; United States Department of Agriculture Foreign Agriculture Service: Washington, DC, USA, 2019; pp. 1-11.

3. Khan, M.K.; Huma, Z.E.; Dangles, O. A comprehensive review on flavanones, the major citrus polyphenols. J. Food Compos. Anal. 2014, 33, 85-104. [CrossRef]

4. Graham, J.H.; Gottwald, D.T.R.; Cubero, J.; Achor, D.S. Xanthomonas axonopodis pv. citri: Factors affecting successful eradication of citrus canker. Mol. Plant Pathol. 2004, 5, 1-15. [CrossRef] [PubMed]

5. Gottwald, T.R.; Graham, J.H.; Schubert, T.S. Citrus canker: The pathogen and its impact. Plant Manag. Netw. 2002. [CrossRef] 
6. Rigano, L.A.; Marano, M.R.; Castagnaro, A.P.; Do Amaral, A.M.; Vojnov, A.A. Rapid and sensitive detection of citrus bacterial canker by loop-mediated isothermal amplification combined with simple visual evaluation methods. BMC Microbiol. 2010, 10, 176. [CrossRef]

7. Moreira, L.M.; Almeida, N.F.; Potnis, N.; Digiampietri, L.A.; Adi, S.S.; Bortolossi, J.C.; da Silva, A.C.; da Silva, A.M.; de Moraes, F.E.; de Oliveira, J.C.; et al. Novel insights into the genomic basis of citrus canker based on the genome sequences of two strains of Xanthomonas fuscans subsp. aurantifolii. BMC Genom. 2010, 11, 238. [CrossRef]

8. Cubero, J.; Graham, J.H. Genetic relationship among worldwide strains of Xanthomonas causing canker in citrus species and design of new primers for their identification by PCR. Appl. Environ. Microbiol. 2002, 68, 1257-1264. [CrossRef]

9. Ryan, R.P.; Vorhölter, F.J.; Potnis, N.; Jones, J.B.; Van Sluys, M.-A.; Bogdanove, A.J.; Dow, J.M. Pathogenomics of Xanthomonas: Understanding bacterium-plant interactions. Nat. Rev. Microbiol. 2011, 9, 344-355. [CrossRef]

10. Silva, A.C.R.; Ferro, J.A.; Reinach, F.C.; Farah, C.S.; Furlan, L.R. Comparison of the genomes of two Xanthomonas pathogens with differing host specificities. Nature 2002, 417, 459-463. [CrossRef]

11. Ference, C.M.; Gochez, A.M.; Behlau, F.; Wang, N.; Graham, J.H.; Jones, J.B. Recent advances in the understanding of Xanthomonas citri ssp. citri pathogenesis and citrus canker disease management. Mol. Plant Pathol. 2018, 19, 1302-1318. [CrossRef]

12. Pitino, M.; Armstrong, C.M.; Duan, Y. Rapid screening for citrus canker resistance employing pathogen-associated molecular pattern-triggered immunity responses. Hortic. Res. 2015, 2, 1-8. [CrossRef] [PubMed]

13. Gottwald, T.R.; Hughes, G.; Graham, J.H.; Sun, X.; Riley, T. The citrus canker epidemic in Florida: The scientific basis of regulatory eradication policy for an invasive species. Phytopathology 2000, 91, 30-34. [CrossRef] [PubMed]

14. Behlau, F.; Canteros, B.I.; Minsavage, G.V.; Jones, J.B.; Graham, J.H. Molecular characterization of copper resistance genes from Xanthomonas citri subsp. citri and Xanthomonas alfalfae subsp. citrumelonis. Appl. Environ. Microbiol. 2011, 77, 4089-4096. [CrossRef] [PubMed]

15. Cooksey, D.A.; Azad, H.R.; Cha, J.S.; Lim, C.K. Copper resistance gene homologs in pathogenic and saprophytic bacterial species from Tomato. Appl. Environ. Microbiol. 1990, 56, 431-435. [PubMed]

16. Silva, I.C.; Regasini, L.O.; Petrãnio, M.S.; Silva, D.H.S.; Bolzani, V.S.; Belasque, J.; Sacramento, L.V.S.; Ferreira, H. Antibacterial activity of alkyl gallates against Xanthomonas citri subsp. citri. J. Bacteriol. 2013, 195, 85-94. [CrossRef] [PubMed]

17. Graham, J.H.; Leite, R.P.; Yonce, H.D.; Myers, A.M. Streptomycin controls citrus canker on sweet orange in Brazil and reduces risk of copper burn on grapefruit in Florida. Proc. Fla. State Hort. Soc. 2008, 121, 118-123.

18. Chen, X.H.; Scholz, R.; Borriss, M.; Junge, H.; Mogel, G.; Kunz, S.; Borriss, R. Difficidin and bacilysin produced by plant-associated Bacillus amyloliquefaciens are efficient in controlling fire blight disease. J. Biotechnol. 2009, 140, 38-44. [CrossRef]

19. Liu, B.; Qiao, H.; Huang, L.; Buchenauer, H.; Han, Q.; Kang, Z.; Gong, Y. Biological control of take-all in wheat by endophytic Bacillus subtilis E1R-j and potential mode of action. Biol. Control 2009, 49, 277-285. [CrossRef]

20. Gouda, S.; Das, G.; Sen, S.K.; Shin, H.S.; Patra, J.K. Endophytes: A treasure house of bioactive compounds of medicinal importance. Front. Microbiol. 2016, 7, 1-8. [CrossRef]

21. Chen, X.H.; Koumoutsi, A.; Scholz, R.; Eisenreich, A.; Schneider, K.; Heinemeyer, I.; Morgenstern, B.; Voss, B.; Hess, W.R.; Reva, O.; et al. Comparative analysis of the complete genome sequence of the plant growth-promoting bacterium Bacillus amyloliquefaciens FZB42. Nat. Biotechnol. 2007, 25, 1007-1014. [CrossRef]

22. Paulsen, I.T.; Press, C.M.; Ravel, J.; Kobayashi, D.Y.; Myers, G.S.A.; Mavrodi, D.V.; DeBoy, R.T.; Seshadri, R.; Ren, Q.; Madupu, R.; et al. Complete genome sequence of the plant commensal Pseudomonas fluorescens Pf-5. Nat. Biotechnol. 2005, 23, 873-878. [CrossRef] [PubMed]

23. Strobel, G.; Daisy, B. Bioprospecting for microbial endophytes and their natural products. Microbiol. Mol. Biol. Rev. 2003, 67, 491-502. [CrossRef] [PubMed]

24. Hallmann, J.; Quadt-Hallmann, A.; Mahaffee, W.F.; Kloepper, J.W. Bacterial endophytes in agricultural crops. Can. J. Microbiol. 1997, 43, 895-914. [CrossRef] 
25. Nisa, H.; Kamili, A.N.; Nawchoo, I.A.; Shafi, S.; Shameem, N.; Bandh, S.A. Fungal endophytes as prolific source of phytochemicals and other bioactive natural products: A review. Microb. Pathog. 2015, 82, 50-59. [CrossRef] [PubMed]

26. Hentschel, U.; Steinert, M.; Hacker, J. Common molecular mechanisms of symbiosis and pathogenesis. Trends Microbiol. 2000, 8, 226-231. [CrossRef]

27. Cao, Y.; Pi, H.; Chandrangsu, P.; Li, Y.; Wang, Y.; Zhou, H.; Xiong, H.; Helmann, J.D.; Cai, Y. Antagonism of two plant-growth promoting Bacillus velezensis isolates against Ralstonia solanacearum and Fusarium oxysporum. Sci. Rep. 2018, 8, 1-14. [CrossRef] [PubMed]

28. Wu, L.; Wu, H.; Chen, L.; Yu, X.; Borriss, R.; Gao, X. Difficidin and bacilysin from Bacillus amyloliquefaciens FZB42 have antibacterial activity against Xanthomonas oryzae rice pathogens. Sci. Rep. 2015, 5, 1-9. [CrossRef] [PubMed]

29. Ge, B.; Liu, B.; Nwet, T.T.; Zhao, W.; Shi, L.; Zhang, K. Bacillus methylotrophicus strain NKG-1, isolated from changbai mountain, China, has potential applications as a biofertilizer or biocontrol agent. PLoS ONE 2016, 11, e0166079. [CrossRef] [PubMed]

30. Masum, M.M.I.; Liu, L.; Yang, M.; Hossain, M.M.; Siddiqa, M.M.; Supty, M.E.; Ogunyemi, S.O.; Hossain, A.; An, Q.; Li, B. Halotolerant bacteria belonging to operational group Bacillus amyloliquefaciens in biocontrol of the rice brown stripe pathogen Acidovorax oryzae. J. Appl. Microbiol. 2018, 11, 1-13. [CrossRef] [PubMed]

31. Asaka, O.; Shoda, M. Biocontrol of Rizhoctonia solani damping-off of Tomato with Bacillus subtilis RB14. Appl. Environ. Microbiol. 1996, 62, 4081-4085. [PubMed]

32. Chen, L.; Heng, J.; Qin, S.; Bian, K. A comprehensive understanding of the biocontrol potential of Bacillus velezensis LM2303 against Fusarium head blight. PLoS ONE 2018, 13, e0198560. [CrossRef] [PubMed]

33. Cawoy, H.; Bettiol, W.; Fickers, P.; Ongena, M. Bacillus-based biological control of plant diseases. Pestic. Mordern World-Pestic. Use Manag. 2009, 1849, 273-298.

34. Rabbee, M.F.; Ali, M.S.; Choi, J.; Hwang, B.S.; Jeong, S.C.; Baek, K. Bacillus velezensis: A valuable member of bioactive molecules within plant microbiomes. Molecules 2019, 24, 1046. [CrossRef] [PubMed]

35. Dunlap, C.A.; Kim, S.J.; Kwon, S.W.; Rooney, A.P. Bacillus velezensis is not a later heterotypic synonym of Bacillus amyloliquefaciens; Bacillus methylotrophicus, Bacillus amyloliquefaciens subsp. plantarum and 'Bacillus oryzicola' are later heterotypic synonyms of Bacillus velezensis based on phylogenomics. Int. J. Syst. Evol. Microbiol. 2016, 66, 1212-1217. [PubMed]

36. Fan, B.; Blom, J.; Klenk, H.P.; Borriss, R. Bacillus amyloliquefaciens, Bacillus velezensis, and Bacillus siamensis form an "Operational Group, B. amyloliquefaciens" within the B. subtilis species complex. Front. Microbiol. 2017, 8, 1-15. [CrossRef] [PubMed]

37. Scholz, R.; Molohon, K.J.; Nachtigall, J.; Vater, J.; Markley, A.L.; Süssmuth, R.D.; Mitchell, D.A.; Borriss, R. Plantazolicin, a novel microcin B17/streptolysin S-like natural product from Bacillus amyloliquefaciens FZB42. J. Bacteriol. 2011, 193, 215-224. [CrossRef]

38. Scholz, R.; Vater, J.; Budiharjo, A.; Wang, Z.; He, Y.; Dietel, K.; Schwecke, T.; Herfort, S.; Lasch, P.; Borriss, R. Amylocyclicin, a novel circular bacteriocin produced by Bacillus amyloliquefaciens FZB42. J. Bacteriol. 2014, 196, 1842-1852. [CrossRef]

39. Hyun, J.W.; Kim, H.J.; Yi, P.H.; Hwang, R.Y.; Park, E.W. Mode of action of streptomycin resistance in the citrus canker pathogen (Xanthomonas smithii subsp. citri) in Jeju island. Plant Pathol. J. 2012, 28, 207-211. [CrossRef]

40. Araújo, W.L.; Marcon, J.; Maccheroni, W.; Van Elsas, J.D.; Van Vuurde, J.W.L.; Azevedo, J.L. Diversity of endophytic bacterial populations and their interaction with Xylella fastidiosa in citrus plants. Appl. Environ. Microbiol. 2002, 68, 4906-4914. [CrossRef]

41. Guo, Y.; Huang, E.; Yuan, C.; Zhang, L.; Yousef, A.E. Isolation of a Paenibacillus sp. strain and structural elucidation of its broad-spectrum lipopeptide antibiotic. Appl. Environ. Microbiol. 2012, 78, 3156-3165. [CrossRef]

42. Goodson, J.R.; Klupt, S.; Zhang, C.; Straight, P.; Winkler, W.C. LoaP is a broadly conserved antiterminator protein that regulates antibiotic gene clusters in Bacillus amyloliquefaciens. Nat. Microbiol. 2017, 2, 1-10. [CrossRef] [PubMed]

43. Adimpong, D.B.; Sorensen, K.I.; Thorsen, L.; Stuer-Lauridsen, B.; Abdelgadir, W.S.; Nielsen, D.S.; Derkx, P.M.F.; Jespersen, L. Antimicrobial susceptibility of Bacillus strains isolated from primary starters for african traditional bread production and characterization of the bacitracin operon and bacitracin biosynthesis. Appl. Environ. Microbiol. 2012, 78, 7903-7914. [CrossRef] [PubMed] 
44. Nanda, S.S.; Yi, D.K.; Kim, K. Study of antibacterial mechanism of graphene oxide using Raman spectroscopy. Sci. Rep. 2016, 6, 1-12. [CrossRef] [PubMed]

45. Chang, S.C.; Deng, W.L.; Huang, H.C.; Chung, K.R.; Tzeng, K.C. Differential expression of pectolytic enzyme genes in Xanthomonas citri subsp. citri and demonstration that pectate lyase Pel3 is required for the formation of citrus canker. Microbiol. Res. 2016, 192, 1-10. [CrossRef] [PubMed]

46. Rosenblueth, M.; Martínez-Romero, E. Bacterial endophytes and their interactions with hosts. Mol. Plant-Microbe Interact. 2006, 19, 827-837. [CrossRef]

47. Huang, T.P.; Tzeng, D.D.S.; Wong, A.C.L.; Chen, C.H.; Lu, K.M.; Lee, Y.H.; Huang, W.D.; Hwang, B.F.; Tzeng, K.C. DNA polymorphisms and biocontrol of Bacillus antagonistic to citrus bacterial canker with indication of the interference of phyllosphere biofilms. PLOS ONE 2012, 7, e42124. [CrossRef]

48. Melnick, R.L.; Zidack, N.K.; Bailey, B.A.; Maximova, S.N.; Guiltinan, M.; Backman, P.A. Bacterial endophytes: Bacillus spp. from annual crops as potential biological control agents of black pod rot of cacao. Biol. Control 2008, 46, 46-56. [CrossRef]

49. Kloepper, J.W.; Ryu, C.-M.; Zhang, S. Induced systemic resistance and promotion of plant growth by Bacillus spp. Phytopathology 2004, 94, 1259-1266. [CrossRef]

50. Chowdhury, S.P.; Uhl, J.; Grosch, R.; Alquéres, S.; Pittroff, S.; Dietel, K.; Schmitt-Kopplin, P.; Borriss, R.; Hartmann, A. Cyclic lipopeptides of Bacillus amyloliquefaciens subsp. plantarum colonizing the Lettuce rhizosphere enhance plant defense responses toward the bottom rot pathogen Rhizoctonia solani. Mol. Plant-Microbe Interact. 2015, 28, 984-995. [CrossRef]

(C) 2019 by the authors. Licensee MDPI, Basel, Switzerland. This article is an open access article distributed under the terms and conditions of the Creative Commons Attribution (CC BY) license (http://creativecommons.org/licenses/by/4.0/). 